УДК 355.45.02

Федір Саганюк,

кандидат юридичних наук, доцент Національний університет оборони України імені Івана Черняховського, м.Київ

ORCID ID 0000-0002-9516-0562

DOI: $10.33099 / 2617-1775 / 2021-01 / 305-313$

\title{
ПІДХОДИ ДО ЗАСТОСУВАННЯ НАУКОВИХ ШКІЛ МЕНЕНДЖМЕНТУ У СФЕРІ ВІЙСЬКОВОЇ ОСВІТИ
}

В статті розглянуті теоретичні та практичні підходи наукових шкіл менеджменту у сфері військової освіти..

Ключові слова: Збройні Сили Украӥни; військова освіта; менеджмент; сили оборони.

Постановка проблеми. Зміни у глобальному безпековому середовищі та навколо України свідчать про подальше взаємне проникнення та інтегрування військових і невійськових технологій у процеси запобігання, стримування і розв'язання кризових ситуацій воєнного характеру та воєнних конфліктів.

3 цієї точки зору стратегічним завданням університету залишається забезпечення високого рівня військової освіти для ефективної реалізації управлінських рішень у сфері військової освіти [1].

Аналіз публікацій. Розвиток наукової теорії і практики менеджменту має давню історію. Перші згадування про них відображені у письмових джерелах Шумерської держави (III тисячоліття до н.е.), Месопотамії і стародавнього Китаю.

Зародження підходів наукових шкіл менеджменту в практику дій знайшло відбиток у працях Ніколо Макіавеллі (1469 - 1527), у яких він зробив спробу сформулювати рекомендації щодо організації державного управління.

Подальші пошуки наукових підходів у цій сфері почалися в епоху капіталізму. Зокрема, англійці Томас Гоббс і Джеймс Стюарт довели, що основною мотивацією людської поведінки являється прагнення до влади, а Бентам у своїй книзі "Уведення в принципи моралі і законодавства" наголосив, що ії мотивами $\epsilon$ користь і задоволення власних потреб.

Широкомасштабний соціальний експеримент у галузі менеджменту в 1800 - 1828 рр. здійснив англійський підприємець і вчений Роберт Оуен. Суть його полягала в наданні працюючим пристойного житла, поліпшенні умов праці і побуту, створенні мережі магазинів, які реалізовували товари першої необхідності за доступною ціною, підвищенні мінімального віку працюючих, скороченні робочого дня, створюванні у робітничих селищах навчальних шкіл.

Вагомий крок у розвиток наукової теорії і практики менеджменту зробив винахідник першої обчислювальної машини Чарльз Беббідж. Він розробив методику вивчення витрат робочого часу під час різних операцій, обгрунтував шляхи підвищення продуктивності праці, а також запровадив преміальну систему їі оплати [2]. 
У минулий період склалося кілька наукових шкіл менеджменту та підходів, що мають певні позитиви для сучасності (табл. 1) [3].

Таблиця 1

\section{Основні школи наукового менеджменту та їх підходи}

\begin{tabular}{|c|c|c|c|}
\hline Школи менеджменту & Основні напрями & Наукові підходи & Представники \\
\hline $\begin{array}{l}\text { Класична школа упр. } \\
\text { (школа наукового } \\
\text { менеджменту); } \\
\text { теорія адміністрування; } \\
\text { теорія ідеальної бюро- } \\
\text { кратії (1885-1920) }\end{array}$ & $\begin{array}{l}\text { Раціоналізація виробничих } \\
\text { та управлінських процесів; } \\
\text { дослідження загальних } \\
\text { проблем управління }\end{array}$ & $\begin{array}{l}\text { Створення наукового фундаменту } \\
\text { управління; } \\
\text { розроблення теорії, принципів і методів } \\
\text { наукового менеджменту; } \\
\text { обгрунтування принципів формальної } \\
\text { організації, проблем лідерства і структури } \\
\text { влади }\end{array}$ & $\begin{array}{l}\text { Ф. Тойлор } \\
\text { А. Файоль } \\
\text { Г. Емерсон } \\
\text { М. Вебер } \\
\text { Г. Форд } \\
\text { Л. Урвік }\end{array}$ \\
\hline $\begin{array}{l}\text { Школа “людських } \\
\text { відносин” } \\
\text { (кінець } 30 \text { рр. ХХ ст.) }\end{array}$ & $\begin{array}{l}\text { Підвищення продуктив-ності } \\
\text { праці за рахунок ство-рення } \\
\text { умов для задоволення } \\
\text { робітників своєю працею та } \\
\text { нормальними стосунками } 3 \\
\text { менеджерами і колегами по } \\
\text { роботі }\end{array}$ & $\begin{array}{l}\text { Визначення ключової ролі людських } \\
\text { відносин в малих групах; } \\
\text { вивчення неформальної соціальної } \\
\text { структури; } \\
\text { створення оптимального соц. - психоло- } \\
\text { гічного клімату; } \\
\text { делегування повноважень і } \\
\text { відповідальності; } \\
\text { мотивація праці підлеглих }\end{array}$ & $\begin{array}{l}\text { Е. Мейо } \\
\text { К. } \\
\text { Арджиріс } \\
\text { Ф. } \\
\text { Херцберг } \\
\text { Д. Мак- } \\
\text { Грегор } \\
\text { Р. Лайкерт }\end{array}$ \\
\hline $\begin{array}{l}\text { Емпірична школа } \\
\text { управління } \\
\text { (середина } 50 \text { рр. ХХ ст.) }\end{array}$ & $\begin{array}{l}\text { Організаційно-технологічні } \\
\text { дослідження організацій; } \\
\text { розроблення новітніх } \\
\text { концепцій сучасного } \\
\text { менеджменту }\end{array}$ & $\begin{array}{l}\text { Збирання і оброблення матеріалів } \\
\text { управлінської практики; } \\
\text { вироблення рекомендацій з удоскона- } \\
\text { лення управління; } \\
\text { вивчення змісту управлінської праці та } \\
\text { функцій керівників; } \\
\text { створення концепції цільового } \\
\text { управління }\end{array}$ & $\begin{array}{l}\text { П. Друкер } \\
\text { Р. Девіс } \\
\text { Л. Ньюмен } \\
\text { Д. Міллер } \\
\text { Г. Мінцберг }\end{array}$ \\
\hline $\begin{array}{l}\text { Школа соціальних } \\
\text { систем (кінець } 60 \text { рр. } \\
\text { ХХ ст.) }\end{array}$ & $\begin{array}{l}\text { Організація як відкрита } \\
\text { соціально-технічна система, } \\
\text { ефективність діяльності якої } \\
\text { залежить не лише від внут- } \\
\text { рішнього, а й від зовніш- } \\
\text { нього середовища }\end{array}$ & $\begin{array}{l}\text { Дослідження найзагальніших форм } \\
\text { організації як соціотехнічної системи; } \\
\text { вирішення проблем конфліктології, } \\
\text { ієрархії потреб і задоволеності працею }\end{array}$ & $\begin{array}{l}\text { Ч. Барнард } \\
\text { Д. Марч } \\
\text { Г. Саймон } \\
\text { А. Енціоні } \\
\text { Т. Парсонс }\end{array}$ \\
\hline $\begin{array}{l}\text { Нова школа наукового } \\
\text { управління (середина } 70 \\
\text { рр. ХХ ст.) }\end{array}$ & $\begin{array}{l}\text { Побудова математичних } \\
\text { моделей менеджменту; } \\
\text { вивчення та моделювання } \\
\text { систем прийняття } \\
\text { управлінських рішень }\end{array}$ & $\begin{array}{l}\text { Розроблення методів математичного } \\
\text { моделювання в управлінні; } \\
\text { визначення алгоритмів вироблення } \\
\text { оптимальних рішень; } \\
\text { розроблення техніко-економічних } \\
\text { моделей соціального розвитку }\end{array}$ & $\begin{array}{l}\text { Р. Акофф } \\
\text { Л. } \\
\text { Берталанфі } \\
\text { С. Бір } \\
\text { К. Боулдінг } \\
\text { Р. Калмен } \\
\text { Л. Клейн } \\
\text { Р. Льюїс } \\
\text { Д. } \\
\text { Форрестер }\end{array}$ \\
\hline $\begin{array}{l}\text { Школа управління } \\
\text { людськими ресурсами } \\
\text { (кінець } 80 \text { рр. XX ст.) }\end{array}$ & $\begin{array}{l}\text { Використання людського } \\
\text { фактора як стратегічного і } \\
\text { життєво необхідного чинника } \\
\text { виживання сучасних } \\
\text { підприємств у складних } \\
\text { умовах ринкового } \\
\text { середовища }\end{array}$ & $\begin{array}{l}\text { Розроблення і вдосконалення } \\
\text { мобілізації працівників за } \\
\text { активної працунок } \\
\text { обліку, використання та розверів, } \\
\text { людського фактора; } \\
\quad \text { визначення і обгрунтування принципів } \\
\text { кадрової політики }\end{array}$ & $\begin{array}{l}\text { Р. Майлз } \\
\text { Ч. Сноу }\end{array}$ \\
\hline $\begin{array}{l}\text { Теорія } \quad \text { людського } \\
\text { потенціалу } \\
\text { (середина } 90 \text { рр. ХХ ст.) }\end{array}$ & $\begin{array}{l}\text { Вивчення залежності доходів } \\
\text { індивіда, підприємства, } \\
\text { суспільства від природних } \\
\text { здібностей людей, їх знань та } \\
\text { навичок; дослідження різних } \\
\text { характеристик потенціалу } \\
\text { людини, що впливають на } \\
\text { зміну доходів; ефективність } \\
\text { інвестицій у професійну } \\
\text { освіту персоналу }\end{array}$ & $\begin{array}{l}\text { Право власності на людський капітал не } \\
\text { може передаватися; } \\
\text { доходи людей зростають із збільшенням } \\
\text { витрат на загальну та професійну освіту; } \\
\text { інвестиції в людський капітал } \\
\text { забезпечують зростання продуктивності } \\
\text { праці та виробництва, розвиток } \\
\text { суспільства }\end{array}$ & $\begin{array}{l}\text { Г. Беккер } \\
\text { Я. Мінсер } \\
\text { Т. Шульц }\end{array}$ \\
\hline
\end{tabular}


В літературі визначено десять основних наукових шкіл, які умовно поділені на три групи. До першої відносять школи, що мають приписний характер. До другої включають школи, що розглядають специфічні аспекти процесу формулювання стратегічних дій. Їх підходи відносяться не стільки до змісту поведінки, а до опису реальних процесів. До третьої відносить школу конфігурації тобто підходи, що виходять із змісту дій, процесу їх формування, організаційної структури і зовнішнього середовища [4].

Однак, у згаданих та деяких інших публікаціях конкретні методологічні й методичні підходи для здійснення ефективнішого розвитку оборонного менеджменту в оборонній сфері в сучасний період недостатньо висвітлені. Вони вимагають певного осмислення і наближення до сучасних потреб 3 урахуванням позитивного досвіду та стандартів, прийнятих у арміях держав членів НАТО.

Метою статті $\epsilon$ пошук прийнятних методологічних та методичних підходів для застосування наукових шкіл менеджменту у сфері військової освіти.

Викладення основного матеріалу. Застосування надбань наукових шкіл менеджменту у Збройних Силах України та інших складових сил оборони, виявило низку проблем, які потребують більш детального вивчення та вирішення, пошуку ефективних підходів наукових шкіл менеджменту до їх подолання, як у сфері оборони, так і у сфері військової освіти. Серед таких наукових шкіл та підходів фахівці відзначають стратегічний, системний, комплексний, інтеграційний, функціональний, нормативний, адміністративний та деякі інші [5].

Стратегічний підхід грунтується на концепції управління, в основі якої лежить розроблення та реалізація самої стратегії. Він дозволяє прогнозувати зміни у зовнішньому середовищі і підготувати війська (сили) до найкращого розвитку їх спроможностей, мінімізувати ризики та можливий вплив зовнішніх загроз.

Стратегічний підхід включає формулювання місії, визначення цілей їх розвитку та діяльності, здійснення стратегічного аналізу, розроблення та реалізацію самої стратегії і стратегічний контроль.

Системний niдxid розглядається як сукупність взаємопов'язаних елементів, що мають вхід, вихід, зворотній зв'язок із зовнішнім середовищем, та визначають їх характер і призначення.

Комплексний niдxiд в управлінській діяльності враховує не тільки економічні, екологічні, технічні, організаційні, соціальні, психологічні наслідки прийняття рішень, але навіть демографічні і політичні аспекти менеджменту та їх взаємозв'язок.

Інтеграційний пiдxid націлений на поглиблення взаємодії суб'єктів управління, їх об'єднання, посилення взаємодії i взаємозв'язку між компонентами цієї системи. Інтеграція забезпечує поглиблення і конкретизацію взаємозв'язків між окремими їх підсистемами.

Цінним для сучасності видається функціональний підхід. За цим підходом потреба (необхідні спроможності) розглядається як сукупність функцій, що 
необхідно виконувати для забезпечення управлінської системи. При впровадженні функціонального підходу виходять від зворотного, а саме від необхідних потреб, в результаті чого створюють нові об'єкти управління, що дозволяє покращити структуру організації та результати ії діяльності.

Міністерство оборони України запропонувало 8 функціональних груп спроможностей Збройних Сил України та інших складових сил оборони, що визначено одним із основних елементів процесу оборонного планування [6]. Кожна з цих груп є сукупністю спроможностей, згрупованих для полегшення їх аналізу, розроблення стратегії їх розвитку, прийняття інвестиційних рішень, а також для планування та управління їх розвитку для досягнення визначених цілей.

Функціональні групи спроможностей Збройних Сил України та інших складових сил оборони визначаються як один із основних елементів процесу оборонного планування. Вони покликані забезпечувати єдиний понятійний апарат в ході оборонного планування, управління ресурсами, а також планування та управління розвитком спроможностей військ (сил). Кожна 3 них в ході оцінювання має деталізуватися для визначення необхідних спроможностей на стратегічному, оперативному і тактичному рівнях. На кожному з цих рівнів можуть бути кілька груп або підгруп спроможностей.

Функиіональну модель управління, як обгрунтовують автори [7], використовують за наявності великої кількості спеціалізованих робіт. Для цього передбачається групування спеціалістів та підрозділів, що виконують схожі функції. Тут обов'язкове для усіх підрозділів виконання вказівок функціональних органів (відділів планування, постачання, обслуговування) у межах їх компетенції.

Функціональна модель управління спрямована на виконання завдань, що постійно повторюються і не потребують оперативних рішень. Вона може бути оптимальною для підрозділів, що діють у стабільних умовах. Її переваги: висока компетентність фахівців, які відповідають за виконання окремих функцій; розширення можливостей керівників підрозділів щодо оперативного управління, вивільнення їх від вирішення питань функціональної діяльності тощо.

Однак, при цьому підході суттєво утруднене підтримання постійних взаємозв'язків між різними службами, досить тривала процедура прийняття рішень, є брак взаєморозуміння і єдності дій представників функціональних служб різних підрозділів; зменшення відповідальності виконавців за роботу внаслідок відходу від принципу єдиноначальності керівництва.

У інших умовах, на думку згаданих авторів, може використовуватися лінійно-функиіональна модель управління, яка передбачає, що лінійному менеджеру при виконанні конкретних завдань і підготовці відповідних рішень, програм, планів допомагають функціональні служби. Вони доводять свої рішення до виконавців через керівництво або безпосередньо у межах спеціальних повноважень, здійснюють усю технічну підготовку запланованого процесу, готують певні варіанти вирішення поставлених завдань, пов'язаних 3 
управлінням цим процесом; вивільняють керівників виконавчих підрозділів від планування, фінансових розрахунків, матеріально-технічного забезпечення.

Перевага даного підходу у єдності та чіткості управління, оперативному прийнятті та виконанні рішень, а також у особистій відповідальності кожного керівника за результати діяльності підрозділів і у професійному вирішенні завдань фахівцями функціональних служб.

Разом 3 цим тут можуть бути присутні суперечності між менеджерами i функціональними службами; їх протидія діяльності функціональних фахівців; неправильне тлумачення інформації, яка передається виконавцям функціональними менеджерами.

Інші підходи сучасного менеджменту. Суттєвим в літературі представлений нормативний nidxid, за яким встановлюються певні нормативи управління за всіма важливими елементами підсистем менеджменту: цільовий, функціональний та забезпечення. Нормативи повинні відповідати вимогам комплексності, ефективності, обгрунтованості та перспективності. Чим більше обгрунтованих нормативів по кожному елементу системи менеджменту, тим вище їі організованість, рівень планування, обліку і контролю.

Адміністративний підхід виражається в регламентації функцій, прав, обов'язків, нормативів якості, витрат, строків, елементів системи менеджменту в нормативних актах (наказах, розпорядженнях, вказівках, стандартах, інструкціях, положеннях тощо).

Cитуаційний підxid заснований на тому, що придатність різних методів управління визначається конкретною ситуацією. Не існує єдиного способу управління об’єктом, оскільки існує безліч факторів, як в самій організації, так i у зовнішньому середовищі. Самим ефективним методом в конкретній ситуації слід вважати той, який більш всього відповідає конкретним умовам i максимально адаптований до них.

Творчий niдxid базується на сукупності прийомів, що характеризують відношення до самого управління, як до свідомого процесу. Прояв творчого підходу - це пошук нетрадиційних рішень, використання нових методів, розроблення оригінальних прийомів. Творчий підхід передбачає генерацію ідей, розроблення і оцінку альтернатив, вміння запозичувати оригінальні ідеї і досвід 3 інших сфер, творчо використовувати їх в управлінні організацією, вміння усвідомлювати накопичений досвід, у тому числі передових держав членів НАТО.

Певний інтерес серед досліджених згаданими вище авторами підходів представляють моделі та структури управління за якими формальна, тобто регламентована сторона управлінської діяльності, переважає над змістовною i творчою [7]. Їх особливості:

вони добре зарекомендували себе у стабільних, незмінних умовах;

проблеми та завдання, з якими стикається організація, розподіляються на кілька дрібних завдань, що доручаються для виконання окремим підрозділам та спеціалістам;

кожний підрозділ вирішує своє завдання уособлено, незалежно від інших; 
права та обов'язки кожного спеціаліста ретельно визначені і не змінюються;

тільки вище керівництво визначає, наскільки завдання, що вирішуються підрозділами, відповідають цілям організації;

зв'язки між підрозділами, що належать до одного рівня організаційної структури, здійснюються через вище керівництво.

Саме до таких моделей управління згадані вище автори відносять функціональну та лінійно-функціональну моделі.

На відміну від них, краще пристосованою до швидких змін зовнішніх умов, зазначені автори відносять адаптивну модель управління, як більш гнучку у порівняні з іншими.

Особливості адаптивної моделі управління:

вона більш пристосована до роботи у нестабільних умовах, коли проблеми, що виникають, та необхідні дії неможливо розкласти на елементи i розподілити між окремими фахівцями чи підрозділами; вони повинні вирішувати поставлені їм завдання, виходячи із загального стану організації; значна частина їх обов'язків у зв'язку із зміною умов постійно переглядається;

виконавці взаємодіють як по горизонталі, так і по вертикалі;

модель не забороняє діяти, обминаючи ієрархічні ступені управління;

за цією моделлю суттєво заохочується ініціатива і творчий підхід до справи.

Адаптивна форма управління краще пристосована до швидкої зміни зовнішніх умов. У ній переважає творча та змістовна сторона над формальною, що сприяє більшій ефективності та результативності самого управління [7].

Школа наукового управління одержала розвиток у США на початку XX століття. Її засновником був американський інженер-дослідник Ф. Тейлор (1856-1915 рр.) Він вважав менеджмент дійсною наукою, яка грунтується на законах, правилах і принципах та зробив важливий висновок, що робота 3 управління - це передусім певна спеціальність.

Тейлор розробив систему наукової організації праці, яка побудована на п’яти основних принципах: науковий підбір кадрів, наукове вивчення праці i навчання працюючих, спеціалізація роботи і спонукальні мотиви до неї.

Особливу важливість серед них представляе науковий підбір кадрів. Ефективна діяльність вимагає підбір на кожне робоче місце чи посаду відповідного співробітника, який має для цього необхідні здібності, які перевіряються системою тестів.

Згодом американський інженер Г. Емерсон (1853-1931pp.) розробив принципи підвищення ефективності не тільки виробничої праці, але доцільної діяльності у державному управлінні, у зовнішній політиці, військовій справі, на транспорті. Ним була опрацьована штабна організація апарату управління, розкрита роль ефективної організації праці і наукових принципів управління, серед яких виділяв точно визначені цілі та принцип здорового глузду.

Авторами шкіл наукового менеджменту та управління доведено, що наукові підходи та методи, які використовуються в науці і техніці, можуть бути ефективно задіяні в практиці діяльності організацій в цілому. Школи наукового 
менеджменту сформулювали принципи і методи наукової організації творчої праці, обгрунтували необхідність ефективної іiі мотивації, як найбільш важливої з усіх підходів [5].

Висновки та перспективи подальших досліджень. В умовах постійних безпекових змін зовнішнього середовища і пов'язаною 3 цим невизначеністю, підвищення ефективності військової освіти шляхом застосування ефективних підходів зазначених вище наукових шкіл менеджменту в сучасний період $\epsilon$ особливо актуальним.

Організація сучасного військового управління за таких підходів вимагає створення нової або перебудови наявної його моделі з урахуванням зазначених наукових шкіл менеджменту та наявного досвіду і творчих підходів до цього процесу, наближених до стандартів, прийнятих у арміях розвинутих держав членів НАТО.

Застосування ефективних підходів наукових шкіл менеджменту у сфері оборони та військової освіти доцільно здійснювати з урахуванням їх надбань, наблизивши цей процес до принципів і стандартів, прийнятих у арміях держав членів НАТО.

Як відзначив начальник Національного університету оборони України імені Івана Черняховського доктор військових наук генерал-лейтенант Сиротенко А. М., "Важливим завданням наукової діяльності $є$ формування сучасного наукового кадрового потенціалу, здатного забезпечити розвиток наукового прогресу у військовій галузі. Належне виконання цього завдання в університеті забезпечують система підготовки науково-педагогічних і наукових кадрів та наукові школи, започатковані та розвинуті провідними вченими університету" [8].

Головна мета цієї діяльності, на його погляд, полягає у здобутті нових наукових знань у сфері національної безпеки і оборони шляхом проведення наукових досліджень та розробок, спрямованих на вирішення проблем забезпечення обороноздатності України, створення та впровадження нової конкурентоспроможної наукової та науково-технічної продукції, підвищення якості підготовки військових фахівців та наукових і науково-педагогічних кадрів.

\section{ЛIТЕРАТУРА}

1. Стратегія НУОУ на період до 2025 року: затв. нак. нач. НУОУ 28.02.2020 № 80. URL: https://nuou.org.ua/assets/documents/nduu-strategy-2025.pdf

2. Бовикін B. I. Новий менеджмент: управління підприємствами на рівні вищих стандартів: теорія і практика ефективного управління. М: ВАТ “Видавн. Економіка”. 1997. $368 \mathrm{c.}$

3. Менеджмент: Навчальний посіб. для вищих навчальних закладів / Щокін Г. В, Головатий М. Ф,. Антонюк О. В, Сладкевич В. П. Київ: МАУП, 2007. 816 с.

4. Дикань В. Л., Зубенко В. О., Маковоз О. В. та ін. Стратегічне управління: навч. посіб. Київ: “Центр уч літ.”, 2013. 272 с.

5. Рульєв В.А., Гуткевич С.О. Менеджмент. Навчальний посібник. Київ: Центр учбової літератури, $2011.312 \mathrm{c.}$

6. Функціональні групи спроможностей МО України, ЗС України та інших складових сил оборони: затв. МО України 09.12.2019. 
7. Сладкевич В. П., Чернявський А. Д. Сучасний менеджмент організацій: навч. посіб. для вищ. навч. закл. Київ: МАУП, 2007. 488 с.

8. Офіційний веб-сайт НУОУ імені Івана Черняховського. URL: https://nuou. org.ua/u/news/privtannya-nachalnika-unversitetu-z-nagodi-dnya-nauki.html

\section{REFERENCES}

1. Strategy of NGOs for the period up to 2025: approved. nak. start HYOY 28.02.2020 № 80. URL: https://nuou.org.ua/assets/documents/nduu-strategy-2025.pdf

2. Bovykin VI New management: enterprise management at the level of higher standards: theory and practice of effective management. M: OJSC "Publishing house. Economy". 1997. $368 \mathrm{p}$.

3. Management: A textbook. for higher educational institutions / Shchokin GV, Golovaty MF ,. Antonyuk OV, Sladkevich VP Kyiv: MAUP, 2007. 816 p.

4. Dykan VL, Zubenko VO, Makovoz OV and others. Strategic management: textbook. way. Kyiv: Center for Educational Literature, 2013. 272 p.

5. Rulev VA, Gutkevich SO Management. Tutorial. Kyiv: Center for Educational Literature, 2011. 312 p.

6. Functional groups of capabilities of the Ministry of Defense of Ukraine, the Armed Forces of Ukraine and other components of the defense forces: approved. Ministry of Defense of Ukraine 12/09/2019

7. Sladkevych VP, Chernyavsky AD Modern management of organizations: textbook. way. for higher textbook lock Kyiv: MAUP, 2007. 488 p.

8. Official website of Ivan Chernyakhovsky NGO. URL: https: // new. org.ua/u/news/privtannya-nachalnika-unversitetu-z-nagodi-dnya-nauki.html

\section{РЕЗЮМЕ}

Фёдор Саганюк

кандидат юридичних наук, доцент Национальный университет обороны Украины имени Ивана Черняховского

\section{Подходы к применению научных школ менеджмента в сфере военного образования}

В статье рассмотрены теоретические и практические подходы научных икол менеджмента в сфрере военного образования.

Ключевые слова: Вооружённые силы Украины; военное образование; менеджмент; сильь оборони.

\section{SUMMARY}

Fedor Sahaniuk,

$\mathrm{PhD}$ in Yurydychnykh Sciences, Assistant professor National Defense University of Ukraine named after Ivan Cherniakhovski

\section{Approaches to the application of scientific schools of management in the field of military education}

The article considers theoretical and practical approaches of scientific schools of management in the field of military education.

Formulation of the problem. Changes in the global security environment and around Ukraine testify to the further mutual penetration and integration of military and non-military 
technologies in the processes of preventing, deterring and resolving military crises and military conflicts.

The aim of the article is to find acceptable methodological and methodological approaches for the application of scientific schools of management in the field of military education.

Conclusions. In the context of constant security changes in the environment and the associated uncertainty, improving the effectiveness of military education through the application of effective approaches of the above scientific schools of management in the modern period is especially relevant.

The organization of modern military management in such approaches requires the creation of a new or restructuring of its existing model, taking into account these scientific schools of management and existing experience and creative approaches to this process, close to the standards adopted in the armies of developed NATO member states.

Keywords: Armed Forces of Ukraine; military education; management; defense forces. 